\title{
Correlations and path analysis for quantitative characteristics in semi-prostrate cowpea bean genotypes (Vigna unguiculata (L.) Walp.)
}

\section{Correlaciones y análisis de sendero para características cuantitativas en genotipos semi-postrados de fríjol caupí (Vigna unguiculata (L.) Walp.)}
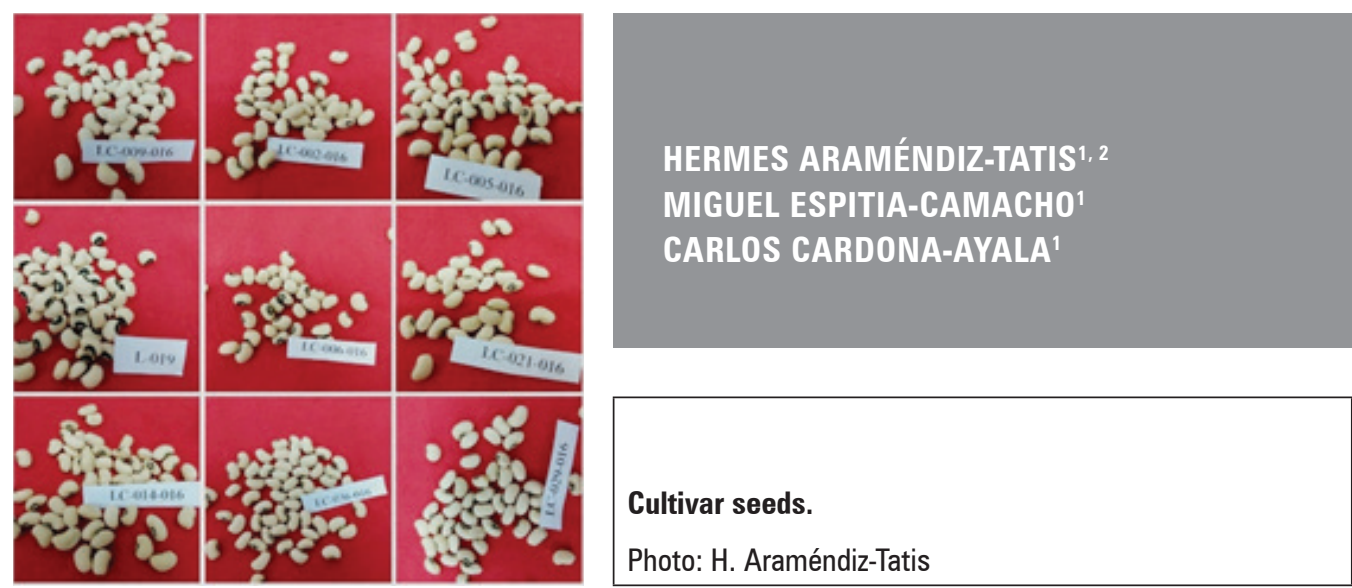

\section{ABSTRACT}

The cowpea is the most important legume in the Colombian Caribbean because of its positive impact on the food and nutritional security of low-income rural families. It is cultivated by small producers but its yields per hectare does not exceed $600 \mathrm{~kg}$ because of the use of obsolete cultivars. The objective of the research was to estimate correlations between seven quantitative characteristics and the path analysis between grain yield and six quantitative characteristics, with the results of the evaluation of 10 genotypes with a semi-prostrate growth habit and high grain yield, grown in eight environments in humid and dry tropics in the Colombian Caribbean region. A randomized complete blocks design was used, with four repetitions. Significant differences between the environments, genotypes and genotype $\times$ environment interaction were detected. The genotypic correlations had a greater magnitude than the phenotypic ones, highlighting the correlation between grain width (GW) and grain yield (GY), $r P=0.69^{*}, \mathrm{rG}=0.78^{*}$, and between the weight of 100 seeds (100SW) and $\mathrm{GW}, \mathrm{rP}=0.97^{* *}, \mathrm{rG}=0.99^{* *}$. The characteristics $\mathrm{GW}$ and number of pods per plant (NPP) had positive direct effects on the GY, with an indirect negative effect on NPP by way of GW. The height of the first pod (HFP), the number of seeds per pod (NSP) and the 100SW directly and negatively influenced the GY of the 10 semi-prostrate cowpea cultivars.

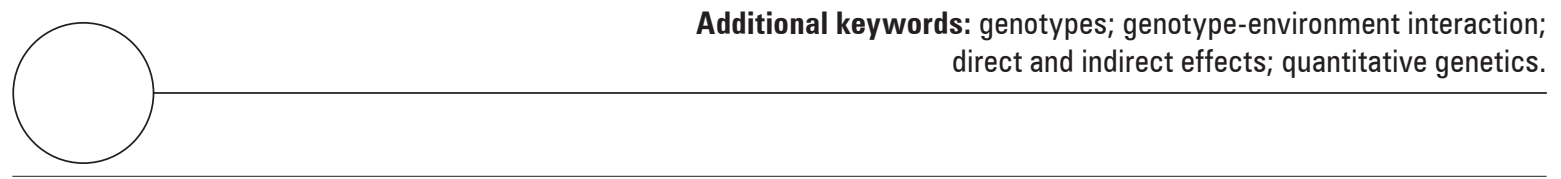
direct and indirect effects; quantitative genetics.

Universidad de Córdoba, Monteria (Colombia). ORCID Araméndiz-Tatis, H.: 0000-0002-2585-6273; ORCID Espitia-Camacho, M.: 0000-0001-7382-9643; ORCID Cardona-Ayala, C.E.: 0000-0002-9607-3858

2 Corresponding author. haramendiz@correo.unicordoba.edu.co 


\section{RESUMEN}

El caupí es la leguminosa más importante del Caribe colombiano, por su impacto positivo en la seguridad alimentaria y nutricional de las familias rurales de escasos ingresos. Es cultivada por pequeños productores, pero sus rendimientos por hectárea no superan los $600 \mathrm{~kg}$, debido al uso cultivares obsoletos. El objetivo de la investigación fue estimar las correlaciones entre siete características cuantitativas y el análisis de sendero entre el rendimiento de grano y seis características cuantitativas, con los resultados de la evaluación de 10 genotipos de hábito de crecimiento semi-postrado, de alto rendimiento de grano, cultivados en ocho ambientes del trópico húmedo y seco de la región Caribe colombiana, bajo el diseño bloques completos al azar, con 10 tratamientos y cuatro repeticiones. Se detectaron diferencias significativas entre ambientes, genotipos e interacción genotipo $\times$ ambiente. Las correlaciones genotípicas fueron de mayor magnitud que las fenotípicas, destacándose la correlación entre el ancho de grano (AG) y el rendimiento de grano (REND), $\mathrm{rF}=0,69^{*}, \mathrm{rG}=0,78^{*}$, igualmente entre el peso de 100 semillas (P100S) y el $\mathrm{AG}, \mathrm{rF}=0,97^{* *}, \mathrm{rG}=0,99 * *$. Los caracteres $\mathrm{AG}$ y número de vainas por planta (NVP) presentaron efectos directos positivos sobre el REND, con efecto indirecto negativo de NVP vía AG, mientras que la altura de la primera vaina (AIPV), el número de semillas por vaina (NSPV) y el P100S influyeron directa y negativamente en el REND de los 10 cultivares de caupí.

Palabras clave adicionales: genotipos; interacción genotipo-ambiente; efectos directos e indirectos; genética cuantitativa.

Received for publication: 16-03-2020 Accepted for publication: 11-06-2020

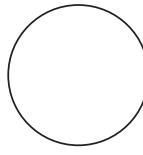

INTRODUCTION

In Colombia, the Caribbean region is the main producer of cowpea beans (Vigna unguiculata (L.) Walp.), a legume species with good adaptation to the climate and soil conditions of the humid and dry tropics because of its short cycle and tolerance to high temperatures and droughts. It is essential for feeding vulnerable populations because of its high percentage of proteins and contents of vitamins, fibers, iron and zinc. Its easy access and low cost satisfy nutritional needs where poverty rates of the region are indicators of multidimensional poverty, which increased 7.1\% from 2016 to 2018 (De Paula et al., 2018; Dane, 2019).

The cowpea bean is cultivated mainly by farmers under the rural family agriculture scheme, which is characterized by the use of uncertified seeds from unimproved cultivars of semi-prostrate architecture that are susceptible to abiotic and biotic factors, whose yields per hectare does not exceed $600 \mathrm{~kg}$. because of the low application of technology in this crop. Colombia has been forced to import 14,894 to satisfy domestic demand (Fenalce, 2017). This situation has led to the improvement of cultivars with greater genetic potential for use in both family and business agriculture to reduce imports, improve food security, minimize problems of hidden hunger and reduce human migration from the countryside to cities.
Grain yield is a quantitative trait affected by the environment, and its direct selection is inefficient because of the variation of climate and soils. The behavior of cultivars under different environmental conditions is affected by their interaction with the environments, which leads to variable expressions of yield. This is directly and indirectly correlated with other traits (Ullah et al., 2011). Therefore, effective selection requires information on correlations between grain yield and other traits, including components. However, this correlation does not clearly discriminate the direct and indirect effects of such traits because of alterations that may occur because of the selection pressure (Bhatt, 1973; Ribeiro et al., 2016).

Path analysis is an important statistical technique that verifies the direct and indirect contribution of a set of independent variables on a dependent variable, such as yield, which is important in the selection process. For cowpea beans, the identification of direct and indirect effects of independent traits is important in the selection of cultivars that can satisfy Colombia's needs. This technique has been applied in the genus Vigna by Meena et al. (2015); Hemavathy et al. (2015); and Ribeiro et al. (2016). 
The objective of the research was to estimate correlations between seven quantitative traits and the direct and indirect effects of six independent traits on the grain yield of cowpea beans using path analysis.

\section{MATERIALS AND METHODS}

The study was carried out in eight environments of the Colombian Caribbean, representative of the humid and dry tropics: Sampues-Sucre, Monteria Cordoba, Leticia - Bolivar, Polonuevo - Atlantico and Villanueva - Guajira, during the second half of 2017 and first half of 2018.

Nine advanced lines obtained from the genetic improvement program of the Universidad de Córdoba were studied: LC-029-016; LC-002-016; LC-036-016; LC-009-016; LC-021-016, L-019; LC-006-016; LC-005016, and LC-014, and Caupicor 50 as the commercial control (Tab. 1). These genotypes are semi-prostrated and precocious with cream seeds with black hilum that are preferred by consumers.

Table 1. Name and origin of the 10 semi-prostrate cowpea bean genotypes evaluated in Colombian wet and dry Caribbean environments.

\begin{tabular}{|l|c|c|}
\hline Genotype & Genotype & Origin \\
\hline LC-029-016 & Line & Colombia \\
\hline LC-002-016 & Line & Colombia \\
\hline LC-036-016 & Line & Colombia \\
\hline LC-009-016 & Line & Colombia \\
\hline LC-021-016 & Line & Colombia \\
\hline LC-019 & Line & Colombia \\
\hline LC-006-016 & Line & Colombia \\
\hline LC-005-016 & Line & Colombia \\
\hline LC-014-016 & Line & Colombia \\
\hline Caupicor 50 & Commercial genotype & Colombia \\
\hline
\end{tabular}

Seven agronomic characteristics, days to flowering (DF), height of first pod (HFP), number of pods per plant (NPP), number of seeds per pod (NSP), 100 seeds weight (100SW), width of grain (GW) and grain yield (GY), were measured.

The design used randomized complete blocks with 10 treatments and four repetitions. The experiment plots were $3.2 \mathrm{~m}$ wide by $5 \mathrm{~m}$ long, for an area of $16 \mathrm{~m}^{2}$. The grain yield data and the rest of the traits were subjected to a combined analysis of variance, covariance and means tests. For the estimation of phenotypic and genetic correlations and the path analysis for GY, the free access computer program GENES Windows version GENES V.2016.6.0 (Cruz, 2016) was used.

Based on the estimated phenotypic and genetic correlations between the seven variables, two path analyses were performed for the system: GY as an effect variable $(\mathrm{Y})$ based on the cause variables: DF (X1), HFP (X2), NPP (X3), NSP (X4), 100SW (X5) and GW (X6). The two path analyses were originated from the phenotypic and genotypic correlations between the variables.

\section{RESULTS AND DISCUSSION}

\section{Variance analysis}

The combined analysis of variance showed the significant influence of the environment on the 10 genotypes in all response variables. Significant differences between the genotypes were observed in six of the seven variables, excluding NPP (Tab. 2). The interaction of the 10 genotypes with the eight environments was significant in all variables; therefore, the genotypes were influenced by the environmental conditions of each locality. This sensitivity to environmental effects generates changes in the classification or range of genotypes among environments, hides the expression of characteristics of interest, decreases the correlation between phenotypic and genotypic values, reduces the progress of selection and makes selection and subsequent recommendations of genotypes for one or several locations difficult (Kumar et al., 2013; Abate et al., 2015; Ferrari et al., 2018). According to Mendonça et al. (2007), the presence of a genotype $\times$ environment interaction, justifies environmental stratification in order to take advantage of environmental stimuli that favor genotype expressions.

The experiment precision of the study according to the registered coefficients of variation was acceptable. The records ranged from low to medium according to Oliveira et al. (2009), providing reliable and valid conclusions.

\section{Correlations}

The phenotypic and genotypic correlation coefficients estimated for the seven variables are shown 
Table 2. Mean squares and level of significance of the analysis of combined variance for agronomic characteristics of 10 cowpea bean semi-prostrate genotypes evaluated in the Colombian Caribbean.

\begin{tabular}{|l|c|c|c|c|c|c|c|c|}
\hline $\begin{array}{l}\text { Source of } \\
\text { variation }\end{array}$ & $\begin{array}{c}\text { Degree of } \\
\text { freedom }\end{array}$ & DF & HFP & NPP & NSP & 100SW & GW & GY \\
\hline Environments (E) & 7 & $411.52^{* *}$ & $1960.74^{* *}$ & $5929.68^{* *}$ & $67.67^{* *}$ & $62.50^{* *}$ & $0.011^{* *}$ & $8563295.50^{* *}$ \\
\hline Reps. within E & 24 & 12.24 & 60.24 & 42.14 & 1.33 & 2.98 & 0.001 & 101754.18 \\
\hline Genotypes (G) & 9 & $48.95^{* *}$ & $918.75^{* *}$ & $165.16^{\text {NS }}$ & $5.16^{*}$ & $110.39^{* *}$ & $0.045^{* *}$ & $1115131.34^{* *}$ \\
\hline G $\times$ E & 63 & $9.31^{* *}$ & $65.52^{* *}$ & $81.76^{* *}$ & $1.99^{* *}$ & $3.68^{* *}$ & $0.001^{* *}$ & $214723.14^{* *}$ \\
\hline Error & 216 & 5.69 & 16.23 & 21.29 & 1.17 & 1.88 & 0.0008 & 47988.19 \\
\hline CV (\%) & & 6.23 & 8.75 & 16.75 & 9.19 & 9.37 & 4.95 & 19.3 \\
\hline
\end{tabular}

$\mathrm{DF}=$ days to flowering; HFP $=$ height of the first pod; NPP = number of pods per plant; NSP $=$ number of seeds per pod; $100 \mathrm{SW}=100$ seeds weight, GW $=$ width of grain; $\mathrm{GY}=$ grain yield. Ns not significant; ${ }^{* *}$ significant at $P<0.01$.

in table 3. Only four phenotypic correlations and 10 genotypic correlations were significant out of a total of 21 for each one. In general, the coefficients of genotypic correlations were of greater magnitude than the phenotypic ones, and, because of their greater genetic contribution (Silva and Neves, 2011; Ullah et al., 2011; Agrawal et al., 2018) they allowed better selection. In addition, not all characteristics were significantly correlated, which is consistent with the report by Bezerra et al. (2001) and Meena et al. (2015). The positive genetic correlations between two variables make the improvement of both characteristics much easier because, by exerting selection pressure on one, the other is indirectly affected in the same way because of the joint action of genes that govern them or the pleiotropic action between these characteristics (Gupta et al., 2017).
The phenotypic correlations between DF and the other response variables were not significant, while the genotypic ones showed a positive and significant correlation with the height of the first pod (HFP) rG $=0.66^{*}$ and number of pods per plant (NPP) $\mathrm{rG}=$ $0.70^{*}$. In addition, there was a negative and significant correlation with the number of seeds per pod (NSP) $r G=-0.66^{*}$ (Tab. 3) that will allow breeders to select plants that flower later in time with a higher HFP and NPP, providing more progress than direct selection. Contact between the pods and soil is avoided, pod rot is reduced, and both manual and mechanical harvesting is facilitated (Salinas et al., 2008; Silva et al., 2014). Simultaneously, a lower NSP is achieved through the competition of photoassimilates for grain filling. These results are consistent with previous reports by Mohammed et al. (2010); Hemavathy

Table 3. Phenotypic (rP) and genotypic (rG) correlation coefficients between 7 agronomic characteristics in ten cowpea semiprostrate genotypes.

\begin{tabular}{|c|c|c|c|c|c|c|c|}
\hline Character & $\begin{array}{l}\text { Correlation } \\
\text { coefficients }\end{array}$ & HFP & NPP & NSP & $100 S W$ & GW & GY \\
\hline \multirow{2}{*}{ DF } & $\mathrm{rP}$ & 0.57 & 0.41 & -0.39 & -0.31 & -0.34 & -0.39 \\
\hline & $\mathrm{rG}$ & $0.66^{*}$ & $0.70^{*}$ & $-0.66^{*}$ & -0.34 & -0.37 & -0.42 \\
\hline \multirow{2}{*}{ HFP } & $\mathrm{rP}$ & & 0.34 & 0.26 & $-0.91^{* *}$ & $-0.92^{* *}$ & -0.59 \\
\hline & rG & & 0.52 & 0.34 & $-0.95^{* *}$ & $-0.95^{* *}$ & $-0.67^{*}$ \\
\hline \multirow{2}{*}{ NPP } & $\mathrm{rP}$ & & & 0.24 & -0.36 & -0.27 & 0.33 \\
\hline & $\mathrm{rG}$ & & & 0.36 & -0.47 & -0.38 & 0.36 \\
\hline \multirow{2}{*}{ NSP } & $\mathrm{rP}$ & & & & -0.52 & -0.50 & -0.03 \\
\hline & $\mathrm{rG}$ & & & & $-0.62^{*}$ & -0.60 & -0.08 \\
\hline \multirow{2}{*}{$100 S W$} & $r P$ & & & & & $0.97^{* *}$ & 0.55 \\
\hline & $r G$ & & & & & $0.99^{* *}$ & $0.64^{*}$ \\
\hline \multirow{2}{*}{ GW } & $r P$ & & & & & & $0.69^{*}$ \\
\hline & $\mathrm{rG}$ & & & & & & $0.78^{*}$ \\
\hline
\end{tabular}

$\mathrm{DF}=$ days to flowering; HFP $=$ height of the first pod; NPP = number of pods per plant; NSP = number of seeds per pod; $100 \mathrm{SW}=100$ seeds weight, GW $=$ width of grain; $\mathrm{GY}=$ grain yield. * significant at $P<0.05 ;{ }^{* *}$ significant at $P<0.01$. 
et al. (2015); and Singh et al. (2018) but divergent from the report by Meena et al. (2015).

Negative and highly significant correlations were recorded between HFP and 100SW $\left(\mathrm{rP}=-0.91^{* *}\right.$ and $\left.\mathrm{rG}=-0.95^{* *}\right), \mathrm{GW}\left(\mathrm{rP}=-0.92^{* *}\right.$ and $\left.\mathrm{rG}=-0.95^{* *}\right)$ and GY ( $\mathrm{rG}=-0.67)$ (Tab. 3), which indicated similar genetic control. In addition, it can be inferred that, in semi-prostrate habit cultivars, improving yield could be done by increasing HFP, making the characteristics 100SW, WG and GY decrease, with a physiological limit in the selection of plants whose architecture favors mechanical harvest and supports a high number of pods per plant, as suggested by Velho et al. (2017).

The NSP did not correlate significantly at the phenotypic level with 100SW, while at the genotypic level the correlation was significant and negative $(\mathrm{rG}=$ $\left.-0.62^{*}\right)$ (Tab. 3) because long pods with many ovules are produced as the result of the competition for photoassimilates, as reported by Bezerra et al. (2001), Andrade et al. (2010), Silva et al. (2014) and Meena et al. (2015). It is possible to select shorter pods with heavier seeds. Similar trends were reported by Andrade et al. (2010), Silva et al. (2014) and Singh et al. (2018).

The absence of significant correlations between NPP and NSP and grain yield is explained by morphological and physiological modifications that were influenced by the environment, which can increase or decrease the magnitude of correlations, as well as the relation of the themselves, as argued by Ferrari et al. (2018).

The phenotypic and genotypic correlations between 100SW and GW behaved similarly, with a high magnitude and significant at $P<0.01\left(\mathrm{rP}=0.97^{* *}\right.$ and $\mathrm{rG}$ $\left.=0.99^{* *}\right)$, as shown in table 3 . An increase in GW facilitates a greater accumulation of biomass and, simultaneously, GY could also increase because the genetic correlation between the GY and GW was positive and significant $\left(\mathrm{rG}=0.78^{*}\right)$, along with $100 \mathrm{SW}$ $\left(\mathrm{rG}=0.64^{*}\right)$, which suggested a linkage or pleiotropic genetic effect. In an improvement program, the GW must be considered because of its effect on 100SW and GY and because of its impact on the commercial value of the grain, which, in the international market, confers economic benefits between 1 and $4 \%$ for the best quality grain (Mishili et al., 2009), especially with a cream color. These significant associations have been shown in previous studies by Moura et al. (2012), Meena et al. (2015), Hemavathy et al. (2015) and Lekshmanan and Vahab (2018). Selection with
100SW, AG and NPP should be considered as the selection criteria for genotypes with the highest production per unit area.

The differences in the correlation coefficients between quantitative characteristics reported by different authors in legumes may be due to differences in genetic variability and environmental conditions (Pantoja et al., 2014).

\section{Path analysis}

The direct and indirect effects of agronomic characteristics on grain yield were estimated by path analysis, as shown in table 4.

Based on the phenotypic correlations, the greatest direct effect on grain yield (GY) was estimated with the GW and a path coefficient of 2.07, followed by 100SW with -0.92 , interpreted as absolute values. The lowest direct effect was estimated with the NSP and 0.15 , followed by DF, HFP and NPP. The results partially agree with those reported by Bezerra et al. (2001); Meena et al. (2015) and Agrawal et al. (2018) in regards to the low contribution of these characteristics to grain yield at the phenotypic level.

The characteristics NPP, HFP and NSP exerted direct, positive effects on grain yield; however, their indirect effects were negative by way of the GW. Selection with NPP and HFP can decrease the grain yield per plant when the purpose is the simultaneous modification of the plant architecture and grain yield because plants with a high number of pods and inserted higher cannot sustain their productive branches if they do not have a larger stem diameter, as indicated by Rocha et al. (2009). However, the contribution of GW and 100SW in the selection of semi-prostrate growth habit plants should be considered because of their simultaneous, negative and positive influence, respectively, on grain yield.

Based on the genotypic correlations, the greatest direct effect was exerted by 100SW with a path coefficient of -13.64 , followed by the GW with 11.42, while the lowest direct effect was obtained with NPP, 0.28 . The characteristics GW, with 11.42, and NPP, with 0.28 , exerted positive, direct effects on the grain yield, while HFP, NSP and 100SW exerted direct, negative effects. The NPP had a direct, positive effect on the grain yield, and its indirect effect on yield was negative by way of the GW. 
Table 4. Direct (diagonal) and indirect (above and below diagonal) path effects of six agronomic characteristics on grain yield in eight cowpea genotypes at the phenotypic (rP) and genotypic (rG) levels.

\begin{tabular}{|c|c|c|c|c|c|c|c|}
\hline Character & DF & HFP & NPP & NSP & $100 S W$ & GW & GY rP \\
\hline DF & -0.36 & -0.21 & -0.15 & 0.14 & 0.11 & 0.13 & -0.39 \\
\hline HFP & 0.25 & 0.43 & 0.15 & 0.11 & -0.39 & -0.39 & 0.59 \\
\hline NPP & 0.21 & 0.18 & 0.52 & 0.12 & -0.19 & -0.14 & 0.33 \\
\hline NSP & -0.06 & 0.04 & 0.04 & 0.15 & -0.08 & -0.08 & -0.03 \\
\hline 100SW & 0.28 & 0.83 & 0.33 & 0.48 & -0.92 & -0.90 & 0.55 \\
\hline \multirow[t]{2}{*}{ GW } & -0.72 & -1.87 & -0.56 & -1.04 & 2.02 & 2.07 & $0.69^{*}$ \\
\hline & $R^{2}=0.984$ & $\mathrm{~h}=0.016$ & & & & & \\
\hline Character & DF & HFP & NPP & NSP & 100SW & GW & GY rG \\
\hline DF & -0.59 & -0.39 & -0.42 & 0.39 & 0.20 & 0.22 & -0.42 \\
\hline HFP & -1.37 & -2.08 & -1.08 & -0.71 & 1.99 & 1.99 & $-0.67^{*}$ \\
\hline NPP & 0.20 & 0.15 & 0.28 & 0.10 & -0.13 & -0.11 & 0.35 \\
\hline NSP & 0.92 & -0.48 & -0.50 & -1.40 & 0.87 & 0.85 & -0.08 \\
\hline 100SW & 4.61 & 13.01 & 6.43 & 8.44 & -13.64 & -13.58 & $0.64^{*}$ \\
\hline \multirow[t]{2}{*}{ GW } & -4.19 & -10.87 & -4.35 & -6.90 & 11.36 & 11.42 & $0.78^{*}$ \\
\hline & $R^{2}=1.000$ & $h=0.000$ & & & & & \\
\hline
\end{tabular}

$\mathrm{DF}=$ days to flowering; HFP = height of the first pod $(\mathrm{cm}) ; \mathrm{NPP}=$ number of pods per plant; NSP = number of seeds per pod; $100 \mathrm{SW}=100 \mathrm{seeds}$ weight $(\mathrm{g})$, $\mathrm{GW}=$ width of grain $(\mathrm{mm}) ; \mathrm{GY}=$ grain yield $\left(\mathrm{kg} \mathrm{ha}^{-1}\right) .{ }^{*}$ significant at $P<0.05$.

The direct, negative effect at the genotypic level of 100SW may be the cause of the poor correlation with performance, as indicated by Santos et al. (2014) and Velho et al. (2017). The importance of 100SW in breeding programs is seen when selecting for an increase in grain yield since it can be affected by GW, NSP and HFP through the competition for assimilates between pods of the same plant (Godim et al., 2008).

The direct effects found at the phenotypic and genotypic levels with respect to grain yield presented a contrasting association in their magnitudes. Similar results were reported by Ferrari et al. (2018) for soybean when stratifying environments into favorable and unfavorable and reporting positive effects in the combined analysis of variance in favorable environments and negative effects in unfavorable environments. These authirs concluded that direct effects are altered by the edaphoclimatic conditions and genetic constitution of the cultivars (Santos et al., 2014) and that environment stratification is a good strategy for minimizing the effects of the genotype $\mathrm{x}$ environment interaction and avoiding variation of the direct effects.

The path analysis at the phenotypic level recorded an $R^{2}=0.984$ and a residual effect of $\mathrm{h}=0.016$. At the genotypic level, the $R^{2}=1.00$ and residual effects (h $=0$ ), which showed that all the variables that contribute to grain yield were included in the present study (Santos et al., 2014).

\section{CONCLUSIONS}

The quantitative characteristics that were more positively correlated with the cowpea grain yield included the 100 seeds weight (100SW) and grain width (GW), while the one with the highest negative correlation was HFP.

The genotypic correlations had a greater magnitude than with the phenotypic ones for the seven quantitative characteristics, highlighting the strong association between grain width and grain yield $\left(\mathrm{rP}=0.69^{*}\right.$; $\left.\mathrm{rG}=0.78^{*}\right)$ and between the 100SW and GW $(\mathrm{rP}=$ $\left.0.97^{* *} ; \mathrm{rG}=0.99^{* *}\right)$.

The characteristics GW and number of pods per plant (NPP) exerted direct, positive effects on grain yield at the genotypic level, with an indirect, negative effect from the NPP by way of the GW. Height of the first pod, number of seeds per pod and 100SW directly and negatively influenced the grain yield (GY) of the 10 cowpea cultivars with a semi-prostrate habit. 


\section{ACKNOWLEDGEMENT}

The authors thank Colciencias, the Universidad de Córdoba and the Fundación Canal del Dique - COMPAS for their financial contributions to the research project "Genetic improvement of cowpea beans ( $\mathrm{Vi}$ gna unguiculata (L.) Walp.), for agronomic and nutritional characteristics adapted to the Colombian Caribbean, for the benefit of vulnerable populations" Code 11271352206.

\section{BIBLIOGRAPHIC REFERENCES}

Abate, F., F. Mekbib, and Y. Dessalegn. 2015. Association of different parametric and non parametric stability models in durum wheat (Triticum turgidum Desf.) genotypes. Int. J. Plant Soil Sci. 7(4), 192-201. Doi: 10.9734/IJPSS/2015/15568

Agrawal, T., A. Kumar, S. Kumar, A. Kumar, R.R. Kumar, S. Kumar, and P.K. Singh. 2018. Correlation and path coefficient analysis for grain yield and yield components in chickpea (Cicer arietinum L.) under normal and late sown conditions of Bihar, India. Int. J. Curr. Microbiol. Appl. Sci. 7(2), 1633-1642. Doi: 10.20546/ ijcmas.2018.702.197

Andrade, F.N., M. Moura Rocha, R. Ferreira-Gomes, F.R. Freire Filho, and S. Ramalho-Ramos. 2010. Estimativas de parâmetros genéticos em genótipos de feijão-caupi avaliados para feijão fresco. Rev. Ciênc. Agron. 41(2), 253-258. Doi: 10.1590/S1806-66902010000200012

Bezerra, A.A., C.J. Anunciação Filho, F.R. Freire Filho, and V.Q. Ribeiro. 2001. Inter-relação entre caracteres de caupi de porte ereto e crescimento determinado. Pesq. Agropec. Bras. 36(1), 137-142. Doi: 10.1590/ S0100-204X2001000100017

Bhatt, G.M. 1973. Significance of path coefficient analysis in determining the nature of the character association. Euphytica 22(2), 338-343. Doi: 10.1007/BF00022643

Cruz, C. 2016. Programa Genes V.2016.6.0 - Aplicativo computacional em genética e estatística. In: http://www. ufv.br/dbg/genes/genes.htm; consulted, March, 2019.

DANE, Departamento Administrativo Nacional de Estadística de Colombia. 2019. Pobreza multidimensional en Colombia 2018. Boletín técnico Mayo -2019. https:// www.dane.gov.co/files/investigaciones/condiciones_vida/pobreza/2018/bt_pobreza_multidimensional_18.pdf; consulted: February, 2019.

De Paula, C.D., S. Jarma, and H. Araméndiz-Tatis. 2018. Caracterización nutricional y determinación de ácido fítico como factor antinutricional del frijol caupí. Agron. Mesoam. 29(1), 29-40. Doi: 10.15517/ma.v29i1.27941

Fenalce, Federación Nacional de Cultivadores de Cereales y Leguminosas of Colombia. 2017. Informe de gestión
2017. http://fenalce.org/siembras/archivos_lt/lt 532IG-FNL-2017-CONSOLIDADO.pdf; consulted: February, 2019.

Ferrari, M., I.V. Carvalho, A.J. Pelegrin, M. Nardino, V.J. Szareski, T. Olivoto, T. Rosa, D.N. Follmann, C. Pegoraro, L.C. Maia, and V.O. Souza. 2018. Path analysis and phenotypic correlation among yield components of soybean using environmental stratification methods. Aust. J. Crop Sci. 12(02), 193-202. Doi: 10.21475/ ajcs.18.12.02.pne488

Godim, T.C., V.S. Rocha, C.S. Sediyama, and G.V. Miranda. 2008. Análise de trilha para componentes do rendimento e caracteres agronômicos de trigo sob desfolha. Pesq. Agropec. Bras. 43(4), 487-493. Doi: 10.1590/ S0100-204X2008000400007

Gupta, R.A., C.N. Ram, S.K. Chakravati, Ch. Deo, M.K. Vishwakarma, D.K. Gautam, and P. Kumar. 2017. Studies on correlation and path coefficient analyses in brinjal (Solanum melongena L.). Int. J. Curr. Microbiol. App. Sci. 6(7), 4543-4548. Doi: 10.20546/ ijcmas.2017.607.474

Hemavathy, A.T., N. Shunmugavalli, and G. Anand. 2015. Genetic variability, correlation and path co-efficient studies on yield and its components in mungbean [Vigna radiata (L.) Wilezek]. Legume Res. 38(4), 442446. Doi: 10.5958/0976-0571.2015.00050.8

Kumar, K.P., P.N. Kumar, T.N. Muneeswari, R. Lamror, and U. Kumari. 2013. Morphological and genetic variation studies in cowpea genotypes [Vigna unguiculata (1.)] Walp. Legume Res. 36(4), 351-354.

Lekshmanan, D.R. and A. Vahab. 2018. Correlation and path coefficient analysis of yield and its component characters among different accessions of cluster bean [Cyamopsis tetragonoloba (L.) Taub.]. Legume Res. 41(1), 53-56. Doi: 10.18805/10.18805/LR-3691

Meena, H.K., K.R. Krishna, and B. Singh. 2015. Character associations between seed yield and its components traits in cowpea [Vigna unguiculata (L.) Walp.]. Indian J. Agric. Res. 49(6), 567-570. Doi: 10.18805/ijare. v49i6.6688

Mendonça, O., V. Carpentieri-Pípolo, D.D. Garbuglio, and N.S. Fonseca Junior. 2007. Factor analysis and environmental stratification in the assessment of soybean adaptability and stability. Braz. J. Agric. Res. 42(11), 1567-1575. Doi: 10.1590/S0100-204X2007001100008

Mishili, F.J., J. Fulton, M. Shehu, S. Kushwaha, K. Marfo, M. Jamal, A. Kergna, and J. Lowenberg-DeBoer. 2009. Consumer preferences for quality characters along the cowpea value chain in Nigeria, Ghana, and Mali. Agribusiness 25(1), 16-35. Doi: 10.1002/agr.20184

Mohammed, M.S., Z. Russom, and S.D. Abdul. 2010. Inheritance of hairiness and pod shattering, heritability and correlation studies in crosses between cultivated cowpea (Vigna unguiculata (L.) Walp.) and its wild 
(var. pubescens) relative. Euphytica 171(3), 397-407. Doi: 10.1007/s10681-009-0058-6

Moura, J., M. Moura Rocha, R. Ferreira Gomes, F. Freire FiIho, K.J. Silva, and V.Q. Ribeiro. 2012. Path analysis of iron and zinc contents and others traits in cowpea. Crop Breed. Appl. Biotechnol. 12(4), 245-252. Doi: 10.1590/S1984-70332012000400003

Oliveira, R.L., J.A. Muniz, M.J. Andrade, and R.L. Reis. 2009. Precisão experimental em ensaios com a cultura do feijão. Ciênc. Agrotec. 33(1), 113-119. Doi: 10.1590/S1413-70542009000100016

Pantoja, D., K.Z. Muñoz, and O.C. Checa. 2014. Evaluación y correlación de componentes de rendimiento en líneas avanzadas de arveja Pisum sativum con gen afila. Rev. Ciênc. Agríc. 31(2), 24-39. Doi: 10.22267/ rcia.143102.29

Ribeiro, H.L., C.A. Santos, L. Diniz, L.A. Nascimento, and E.D. Nunes. 2016. Phenotypic correlations and path analysis for plant architecture traits and grain production in three generations of cowpea. Rev. Ceres 63(1), 033-038. Doi: 10.1590/0034-737X201663010005

Rocha, F., L.D. Barili, S.H. García, R. Modena, J.M.L. Coimbra, A.F. Guidolin, and J.G. Bertoldo. 2009. Seleção em populações mutantes de feijão (Phaseolus vulgaris L.) para caracteres adaptativos. Biotemas 22(2), 19-27. Doi: 10.5007/2175-7925.2009v22n2p19

Salinas, R.A., J.A. Acosta, E. López, C.A. Torres, F.J. Ibarra, and R.F. Gastelum. 2008. Rendimiento y características morfológicas relacionadas con tipo de planta erecta en frijol para riego. Rev. Fitotec. Mex. 31(3), 203-211.

Santos, A., G. Ceccon, L.M. Chamma, A.M. Correa, and V.B. Alves. 2014. Correlations and path analysis of yield components in cowpea. Crop Breed. Appl. Biotechnol. 14(2), 82-87. Doi: 10.1590/1984-70332014v14n2a15

Silva, J.A.L. and J.A. Neves. 2011. Componentes de produção e suas correlações em genótipos de feijãocaupí em cultivo de sequeiro e irrigado. Rev. Ciênc. Agron. 42(3), 702-713. Doi: 10.1590/S1806-66902011000300017

Silva, C.A., M.O. Morais, L.J. Santos, O.L. D’Arede, J.C. Silva, and M.M. Rocha. 2014. Estimativa de parâmetros genéticos em Vigna unguiculata. Rev. Ciênc. Agríc. 37(4), 399-407.

Singh, S.K., V.P. Singh, S. Srivastava, A.K. Singh, B.K. Chaubey, and R.K. Srivastava. 2018. Estimation of correlation coefficient among yield and attributing traits of field pea (Pisum sativum L.). Legume Res. 41(1), 20-26. Doi: 10.18805/LR-3449

Ullah, M.Z., M.J. Hasan, A.H.M.A. Rahman, and A.I. Saki. 2011. Genetic variability, carácter association and path analysis in yard long bean. SAARC J. Agric. 9(2), 9-16.

Velho, L.P., M.S. Gemeli, N. Tevisan, T. Pereira, P. Cerutti, R. Melo, A. Guidolin, J. Coimbra, and S. Correa. 2017. Phenotypic correlation and direct and indirect effects of aerial part components with root distribution of common bean. Pesq. Agropec. Bras. 52(5), 328-334. Doi: 10.1590/s0100-204x2017000500006 